\title{
The Life of Yahya Ibn 'Adi: A Famous Christian Philosopher of Baghdad
}

\author{
Mohd. Nasir Omar \\ Department of Theology and Philosophy, Faculty of Islamic Studies, \\ National University of Malaysia, 43600 Bangi, Selangor, Malaysia \\ abunasir@ukm.edu.my
}

\section{Doi:10.5901/mjss.2015.v6n2s5p308}

\section{Abstract}

Among Christian translators who especially distinguished themselves in the $10^{\text {th }} / 11^{\text {th }}$ century Baghdad were Yahya Ibn 'Adi (d.974), Ibn Zur'ah (d.1008), Ibn al-Khammar (d.1017) and Abu 'Ali al-Samh (d.1027). Some of these Christians were no longer relying on the Caliphs or other patrons of learning, but often found their own means of living which in turn prolonged their own academic interest. Consequently, some of them were no mere translators any more, but genuine scholars. The chief architect among them was Yahya Ibn 'Adi. He was not only the leader of his group but was also dubbed as the best Christian translator, logician and theologian of his times. This is justified, in addition, by his ample productivity in those fields of enquiry. A considerable number of such works have evidently been used by contemporary and later writers, and have also reached us today. Hence we consider that it is in these aspects that his distinctive contributions to scholarship lie, and therefore he deserves more serious study. Thus, this qualitative study which uses content analysis method seeks to introduce Yahya Ibn 'Adi in terms of his history, life, career, education and writings.

Keywords: Yahya Ibn 'Adi, his life, education, career, writings

\section{Yahya's Early Life and Education}

Yahya's full name as given by his biographers, contemporaries and attested by his own testimony is Abu Zakariyya' Yahya Ibn 'Adi Ibn Hamid Ibn Zakariyya' al-Takriti al-Mantiqi (See al-Sijistani 1974; al-Tawhidi 1929; Ibn al-Nadim 1872; and al-Qifti 1903). He received the name Yahya (John) at birth. Later on when he became a father and head of his family, he was given, as customary among the Arabs, the surname taken from one of his sons, "Abu Zakariyya' (father of Zakariyya'); the addition of his ancestors' names to his own, "Yahya Ibn 'Adi (father) Ibn Hamid (grandfather) Ibn Zakariyya' (great grandfather)", is also necessary not only for exactness, but also for avoiding any possible confusion with those of similar name; his nick-name "al-Mantiqi" (the logician), is beyond doubt, awarded to him for his skill at dialectic (Ibn al-Nadim 1872; al-Qifti 1903; and Ibn Abi Usaybi'ah 1982, 1); while his ethnic name, al-Takriti" (the man from Takrit), indicates his home town.

Yahya was born in Takrit (the northern frontier district of 'Iraq) in 893 A.D. of Jacobite or Monophysite Christian parentage. Takrit, the old metropolis of the East, was situated on the right bank of the Tigris, about 100 miles north of Baghdad and almost equidistant from Mawsil. Some writers attribute its foundation to the Sasanian King Sabur, son of Ardashir, and it is also said to have been named after a Christian woman, Takrit bint Wa'il. Later, it was the birth place of al-Malik al-Nasir Salah al-Din Yusuf 1, Saladin (d. 1193), the third crusade hero, whose father Najm al-Din al-Ayyub (d. 1173) was appointed commander of the fortress Takrit under the Saljuq rulers (1055-1100) (Kraemer 1986; Perier 1920).

Takrit was one of the important intellectual centres of that time where both theological and philosophical discussions were held among Christians of different sects, and also between Christians and Muslims. The contemporary Muslim historian, al-Mas'udi (1893) for example, related about a debate he had with the Syrian philosopher and historian, Abu Zakariyya' Dinha' at the Green Church, Takrit in 313 A.H./925 A.D.; and on another occasion al-Mas'udi likewise affirmed that he had seen a voluminous work on ancient philosophy. These hints show that the birth place of Yahya was among the oldest philosophical centres though very much inferior in comparison to Baghdad.

During Yahya's time, the Eastern Church was divided into three main bodies namely: the Nestorians, who dominated Armenia and Persia; the Jacobites or Monophysites, to which Yahya belonged, prevalent in Mesopotamia, Syria and Egypt; and the Melkites (Orthodox) in regions under the Byzantine emperors (Atiyeh 1968). Takrit, Yahya's home town, was the seat of a Jacobite bishop from the fourth century until the middle of the twentieth century, when the diocese was combined with that of al-Mawsil.

Al-Sijistani (1974: 377- 389), who was in contact with each of the three groups, remarked on the diversity of their 
convictions. This was among the earliest indications that has reached us about their diversity. He observes:

"Some of them (Christians) professed that the entities with which (this Being / zat ) unites are human substances. Some among them held that of all these substances that with which it unites is one, namely, the substance of humanity (nasut) of the Messiah (scil. Jesus). These are the Christians, with their divergent opinions concerning this. The Jacobites claim that from the two substances, I mean the substance of humanity (nasut) and the substance of divinity (lahut), one substance and one hypostasis (uqnum) emerge. The Nestorians hold that the union is only through good pleasure, and the two substances remain two and two hypostases. The Melkites hold that two substances and one hypostasis emerge through the union".

The debate between these three Christian confessions, as reflected by the writings of Yahya and his immediate pupils, was bitter. However, though their dogmas, primarily those of the Nestorians and Jacobites, had been condemned as being heretical by the more powerful westerly branches of the Christian church, it is rightly claimed that it was they, particularly the Nestorians, who had played a markedly important role in cultivating Greek sciences and who later transmitted them to the Muslims, and in particular the Muslim philosophers ( Rescher 1964).

As to Yahya's early life and education, biographers leave us ignorant. Nevertheless, we know that, probably after completing his early education in Takrit, Yahya went to Baghdad to continue his studies and pursue his interest sometime between 910 and 915 A.D., when he was aged around 17 to 21. From the epithet "nazil Baghdad" (resident of Baghdad). which is often attached to both his life and career, it may be gathered that he had spent most of his academic life in Baghdad, and become a distinguished scholar at the important centres of learning (al-Qifti 1903; and Ibn al-Ibri 1958). Thus, Yahya seems to have been one of the distinctive scholars at the time, as with many other intellectuals who had received the same title.

Most sources mention Abu Bishr Matta Ibn Yunus (d. 328/940) and Abu Nasr al-Farabi (d. 339/950) as Yahya's teachers in philosophy, particularly logic. The first was the Nestorian logician, physician and translator, reputed in his lifetime as a "master" and "chief authority" on logic in Baghdad, mainly during the reign of Caliph al-Radi (932-939 A.D.). The second was the greatest ever of Muslim Philosophers, the most excellent among the notables, who was wellgrounded in philosophy and famous for almost all of his philosophical writings, which eventually earned him the nickname, "al-Mu'allim al-Thani" (the second teacher), the first being Aristotle. Al-Bayhaqi (1935), states that Yahya was the best (afdal) of al-Farabi's pupils, who summarises the literary works of his master and possesses a compendium of them. This is also confirmed by al-Mas'udi (1893), one of Yahya's associated friends, who reports that he is aware of no one who relies on al-Farabi's philosophy except one man in Baghdad known as Abu Zakariyya' Ibn 'Adi.

Further information supplied by al-Mas'udi (1893) that the basis of Yahya's thought was that of his study of the system (tariqa) of Muhammad Ibn Zakariyya' al-Razi (d. 925), that is, the theory of the Pythagorean on the first philosophy (i.e., metaphysics), tells us of another important master of Yahya. However, it appears that Yahya could have been in contact with al-Razi only for a limited time, possibly somewhere between 910 and 915A.D., just after his migration to Baghdad which was, coincidentally, the period in which al-Razi was reported to have been residing there shortly before returning to his home town al-Rayy (Meyerhof 1930). The precise subjects which Yahya could have studied under al-Razi are not known. Nevertheless, since the latter was "the greatest physician of the Islamic period", and one of the greatest physicians of all time, it was very likely that medicine was their major theme of inquiry, though other disciplines including logic, ethics and metaphysics, as mentioned by al-Mas'udi (d. 957), could also be included (Mayerhof 1984; and Arberry 1957).

Al-Razi (d. 925) also wrote on ethics, al-Tibb al-Ruhani (The Spiritual Medicine), which appeared as "an admirable synthesis of science and metaphysics, shaped in the mind of a master physician and given a verbal form by a master of language" (Arberry 1957). This is in perfect agreement with the subject matter of Yahya's ethics, namely, the correction of the metaphysical side of man, the soul. Further, the fact that he was listed by Ibn Abi Usaybi'a $(1982,1)$ as among the Arabic physicians, may also cause us to believe that al-Razi (d. 925) was a formative influence of Yahya.

Early Arabic sources noted that Yahya also studied with a group of scholars of his day, though none of their names were specifically mentioned. Al-Tawhidi $(1953,1)$, who was in close contact with Yahya as well as with other contemporary men of letters, may indirectly have alluded to this particular group for he named some of them, including Yahya, as his colleagues (ashabuna). Others included al-Sijistani (d.1001), Ibn Zur'a (d.1008), Ibn al-Khammar (d. 1017), Nazif al-Rumi (tenth/eleventh century), al-Qumisi (tenth/eleventh century), Miskawayh (d. 1030), 'Isa b. 'Ali (d. 1001), and others. We do not know for certain which of them Yahya had actually been studying with. However, in seeing that science embodies numerous disciplines, even philosophy, as was usual in those days, encompassing many areas geometry, medicine, astronomy, music, logic and arithmetic - so were the students of science, more particularly the encyclopaedic men of mediaeval Baghdad, very often dubbed with more than one field of specialisation: Yahya himself received the designation of logician, theologian and translator, while Miskawayh received that of historian, ethicist and 
physician.

Hence, the possibility that Yahya could have studied under any particular one of his associates or more, and with other contemporary scholars, especially with those who specialised in different skills from his own, is high. Moreover, most members of the group like al-Sijistani, Ibn Zur'a, Ibn al-Khammar and so forth, studied logic with Yahya, but still acquired additional specialised knowledge from among themselves and from the various experts during their period.

\section{His Career}

Most scholars in those days (during the tenth/eleventh century Baghdad) were no longer dependent on the patronage of the rulers or their viziers, as were their immediate predecessors, but they made their own living as physicians, teachers, scribes, translators, or booksellers (Rescher 1964). Yahya too seems to have earned his own livelihood as a professional copyist and bookseller, a livelihood, which he may have inherited from his father, 'Adi Ibn Hamid. The profession could perhaps be the bread and butter job of many of the literate men of his time (Kraemer 1986; and Walzer 1962). The anecdote given by Ibn al-Nadim (1871-1872), which criticised Yahya for copying too much may substantiate this fact: "Why be amazed at my patience?" Yahya replied. "I have transcribed with my hand two copies of the Tafsir (Qur'anic Commentary) of al-Tabari (d. 923), which I have taken to the kings of the frontiers, and I have copied innumerable works of the Muslim theologians. In fact, I have forced myself to write a hundred pages each day and night, thought I felt this to be little".

Yahya was a prolific copyist of manuscripts and also a keen lover of books, who constantly replenish his book supply for the benefit of his customers as well as for his friends and pupils. Nevertheless, he was not simply a slavish copier, but very often he revised and rectified many of the existing versions and, more importantly, he prepared numerous translations of Greek works mostly from Syriac into Arabic since he knew no Greek (Rescher 1964). Not surprisingly therefore, his contemporary biographer, Ibn al-Nadim (1871-1872), depended on him as a bibliographical source and utilised the catalogue of his books when writing the section on "ancient philosophy" in his well-known book al-Fihrist. Another piece of information again furnished by Ibn al-Nadim (d. 990), that Yahya was distressed by the discovery that the works he had diligently sought for, had already been sold, while still others had been burnt. This confirms his position as an avid collector of books. The fact that he was also designated as a "translator" by Abu Hayyan al-Tawhidi $(1953,1)$, is of course justified by his expertise in such a field in addition to his copious productivity in translation.

Like Miskawayh (d. 1030), Yahya was also listed by Ibn Abi Usaybi'a $(1984,1)$ as among one of the Arabic physicians. But unlike the former, who had been credited by Ibn Abi Usaybi'a with precise medical treatises, Yahya was neither attributed with the works as such nor with any translation of them. Modern scholars including Graf (1910) and Rescher (1964), assert that Yahya earned his livelihood as a qualified medical doctor. We are not aware of the source of such a statement, apart from the tale circulated by one of his fellow countrymen, al-Mas'udi (1893), that Yahya was once the pupil of the great Muslim medical doctor al-Razi (d. 925). This was reinforced by the frank confession made by Yahya himself about his incompetence in medicine, despite being singled out as a physician by Ibn Abi Usaybi'a (1984). In any case, all this lead us to believe that Yahya must also have had some interest in medicine, but does not appear to have practised the art. Even if he did, it was perhaps only a little, or only when forced to do so by circumstances as with his other associated contemporaries, Miskawayh (d. 1030) and Ibn Zur'a (d.1008), who were both counted as physicians by Ibn Abi Usaybi'a. However, no further source informs us whether or not they practised the profession for their living.

Following the death of his master, Matta b.Yunus in 940, and with the absence of al-Farabi (d. 950), who had left Baghdad long before, specifically to travel to study in Syria and Egypt and set himself up at the court of Sayf al-Dawla (d.967) of Aleppo in 942, Yahya became the new leader of philosophical studies in Baghdad. He was now in his late 40s and exercised a truly intellectual sovereignty for the next three decades at the centre; the intellectuals of the new generation, comprising Muslims, Christians, Jews and others alike joined his majlis (school) (Kraemer 1986). Among his celebrated Muslims disciples were al-Sijistani (d. 1001), 'Isa b. 'Ali (d. 1001), Muhammad al-Badihi (d. 990), and Abu Hayyan al-Tawhidi (d. 1023). The Christians were, namely, Ibn Zur'a (d. 1008), Ibn al-Khammar (d. 1017), and Abu 'Ali alSamh (d. 1027). There was also a Jew, Wahab b. Thaqif al-Rumi; and a Sabian, Abu Ishaq al-Sabi' (al-Tawhidi 1953:1; and Kraemer 1986).

Al-Tawhidi (1953), who was a pupil of Yahya as well as a member of the group, tells us that most of his colleagues were prominent in the majlis set up by Yahya, who was also the ustadh (master) of the school. This is attested as well by the reminiscences of two contemporary biographers, Ibn al-Nadim (1871-1872), who considers Yahya as the leader among his associates and unique in his time; and al-Mas'udi (1893), who portrays Yahya as the chief authority of philosophy, particularly logic, during the period. Thus, we notice the continual use of the Alexandrian title, "Head (scholarches / ra'is) of the school" in the tenth/eleventh century Baghdad, and the succession of Abu Bishr Matta b. 
Yunus (d. 940), al-Farabi (d. 950), Yahya Ibn 'Adi (d. 974), and Abu Salayman al-Sijistani (d. 1001), as head of the school.

It is a singular fact that so little is known about the precise syllabus of Yahya's school. The vivid portrayals given by al-Tawhidi (d. 1023) in many of his biographical works, touching particularly on the intellectual life of the period, though centred on the philosophical school of al-Sijistani (d. 1001), echo the ancient sciences as always being the main subjects studied by the succeeding philosophical school of Baghdad. As to that of Yahya, Kraemer (1986), decisively remarks that: "The school of Yahya b. 'Adi, following the lead of its master, engaged mainly in philosophical work; copying, translating, and editing ancient philosophical and scientific texts". Touching on the different interests of its members, J.L. Kraemer further observes that: "Ibn 'Adi's Christian pupils - continued the (predominantly Christian) tradition of meticulous textual editing, translating, and commenting"; whereas his Muslim pupils, "studied and interpreted ancient texts, but they were not as involved in translation and editing - they evinced a keen interest in the history of philosophy".

This educative system, in many respects, is similar to the one adopted by the school of Hunayn Ibn Ishaq (d. 874), about a century earlier as averred by Hunayn himself:

"Our Christian friends (the Nestorians) today assemble every day at those places of instruction known as "school" (schole) for the study of one of the "major works" of the books of the Ancients. But as regards the remaining books, it was customary to read them individually, everyone for himself, after he had grounded himself in the books which I have mentioned, just like our (Nestorians) friends today read the commentaries to the books of the ancients". ( Cited by Rescher 1964: 21-22).

A similar teaching practise appeared to have been adopted by the school of Yahya, though it was not apparently committed to a specific philosophical work or trend. Nevertheless, logic had been the fundamental theme of the voluminous writings of its members and notably its master, as Yahya himself was better-reputed in his lifetime as "the logician" rather than as a "translator", "copyist", "physician", "teacher" or "bookseller"; so were his masters, Abu Bishr Matta (d. 940) and al-Farabi (d. 950), who both successively antedated him as the heads of the school. Even the "school" as a whole was called that of "the logicians" (al-mantiqiyyun). All these indications have persuaded us to conclude that "logic" was probably the focal subject studied by the Yahya school, notwithstanding the fact that other branches of Greek science had also been widely cultivated by its members, as singled out by Kraemer (1986: 7):

"Ibn 'Adi and his pupils corrected and refined previous translations, added their own, deliberated over textual and terminological problems, and engaged in philosophical speculation. The relationship between philosophy and religious doctrine was a major intellectual preoccupation of theirs. The philological finesse and philosophical insight of Ibn 'Adi and his pupils are evident in the editions of Aristotle's Organon and Physics that emanated from his school."

That the Islamic subjects and other fields of learning have also been fostered by the school of Yahya is also evident. Ibn al-Nadim (1871-1872) for instance, relates that Yahya had a keen interest in the works of the Muslim theologians (mutakallimun), as well as in the Qur'anic commentary (tafsir), especially that of al-Tabari (d. 923). Al-Sijistani ( d. 1001), who studied logic with Yahya, on the other hand, proclaimed that his teacher had a high regard for the Indian sciences, but neither al-Sijistani himself nor other sources yielded any further clues concerning this fact. Besides, the other members of the school such as Ibn al-Khammar (d. 1017), 'Isa b. 'Ali (d. 990) and al-Tawhidi (d.1023) also had their own respective areas of curiosity apart from philosophy. For example, the first studied Islamic jurisprudence (figh) and memorised the Qur'an, the second applied himself actively to the science of tradition (hadith), and the third was active in the field of belles-lettres as evoked by his ample productivity in the field.

It seems that Yahya headed his school of philosophy for almost 35 years, from 940 A.D. to 974 A.D. He lived to the ripe old age of eighty-one and died in Baghdad on Thursday 21st of Dhu'l Qa'da 364 A.H., corresponding to 13th August 1285 of the Alexandrian Calender or 974 A. D. He was buried in the church of St. Thomas (Mar Tumar) in Qatiat alRaqiq, north-western Baghdad. His disciple Ibn Zur'a (d. 1008) carved on his tomb the following epitaph

"Often enough the dead remains alive via knowledge, whereas the living dies via ignorance and malaise. Acquire therefore knowledge to gain immortality give no value whatsoever to an ignorant life" (Ibn Abi 'Usaybi'ah 1982-1984, 1).

\section{His Literary Works: Ethics}

Yahya was not a minor writer or a second order philosopher. As a disciple of the most eminent masters of his age, Abu Bishr Matta b. Yunus (d. 940) and al-Farabi (d. 950), he seemed to represent the first, or at least one of the earliest Christian philosophers who was well-grounded in the three major traditions of learning of the time, namely, Greek, Christian and Islamic, although his skill in the first and the second, as reflected in his numerous writings, is much more 
obvious. Among the early Arabic biographers, who deal extensively with the transmission of Greek sciences into the Muslim world during their time, such men as Ibn al-Nadim (1872), al-Qifti (1903) and Ibn Abi Usaybi'a (1984), all admire Yahya's astonishing output. Through Ibn al-Nadim we know most of Yahya's translations and commentaries. Yahya made Arabic translations, from Syriac, of many of Aristotle's major works including Categories, Topica, Sophistica, Poetica, Physica (second section) and one part of Metaphysica, as well as Plato's Law (al-Nawamis).

Yahya also corrected earlier translations of the first fragment of Aristotle's Physica and the whole of Plato's Timaeus. He also wrote a commentary on the former's logical work, Topica, and possessed a compendium of other Greek treatises and commentaries including De Anima, Books of Animals, and Ethics (perhaps the Nicomachean Ethics) of Aristotle, the Republic, Timaeus and other writings of Plato, as well as a number of commentaries by Ammonius, Themistius and Alexander of Aphrodisias. Al-Qifti (d. 1248) and Ibn Abi Usaybi'a (d. 1270), Ibn al-Nadim's close successors, on the other hand, rely heavily on the information supplied by the latter when they both wrote their parallel brief entries on Yahya. Al-Qifti listed altogether 41 titles of Yahya's literary works, whereas Ibn Abi Usaybi'a included seven. Most of these writings, however, are already found scattered in the Fihrist of Ibn al-Nadim (d. 990).

In the constant contact between the three great civilisations, Greek, Muslim and Christian, more especially the last two, as well as the frequent exchange of views, discussions and polemics, Yahya stood then, as agreed by many, as an apologist. Or, we would say, as a scholar who offers a defensive method of argument and concerns himself with the rational justification of Christianity. That is the origin of almost all of his own independent minor treatises. Sometimes they are brief like journal articles, giving replies to objections or questions put to him by others, and sometimes lengthy, with elaboration on Christian dogmas, setting objections, replies and instructions most suitably together.

Perier (1920), was among the first in modern times to provide a comprehensive list of Yahya's works together with their relevant manuscripts in 1920. Soon thereafter Yahya's personal contributions, both on theology and philosophy, mainly the former, received extensive scholarly attention and were featured in almost every piece of research carried out on him. To name but a few, we may include the studies by Endress (1977), al-Takriti (1978), and Samir in (1980). Nevertheless, the one which has been prepared by Endress stands alone in being solely restricted to the literary productions of Yahya, and therefore, represents the most exhaustive inventory on the subject. Since Yahya's writings have already been actively researched on, there is nothing more, as far as we can see, which can be achieved in the research of this nature. However, the significance of this study, especially with regard to the understanding of Yahya's life and works, especially on ethics, remains to be clarified. It is this area that this brief section seeks to clarify.

Notwithstanding the fact that theology was the chief subject of Yahya's thought, while logic, by contrast, was the centre of his philosophical writings, he also produced works on ethics which can be broadly divided into two main groups. The first are those short treatises on some minor aspects of moral practice including Treatise on the Care for Children and their Neglection, A Discussion of Arguments for and Against Celibacy (Maqala wa-Munazara fi Hal Tark Talab alNasl), and Replies to Three Questions on Celibacy, Submitted by Yahya Ibn 'Adi to a Friend in Muharram 353 A. H. / 964 A. D. (ljabat Sadiqina 'Amma Staftaynahu fihi min al-Masa'il al-Thalath al-Warida fi Muharram Sanat 353). Neither the manuscript nor the Arabic title of the first treatise is at present identified; whereas that of the last two are traceable. The second category of Yahy's literature on ethics fall under those works which provide a much more elaborate philosophical analysis. They are his chief ethical treatise Tahdhib al-Akhlaq (The Refinement of Character), and Maqala fi Siyasa alNafs (A Discourse on the Management of the Soul).

The title Tahdhib al-Akhlaq does not appear among Yahya's listed works in the earlier Arabic sources, for example, in Ta'rikh al-Hukama' by al-Qifti (1903), and in 'Uyun al-Anba' fi Tabaqat al-Atibba', by Ibn Abi Usaybi'a (1982), when they both wrote their sections on Yahya; nor was it listed by his close friend Ibn al-Nadim (1871), when he included Yahya's works in his most important catalogue on philosophy among the Arabs, Kitab al-Fihrist. This catalogue ends with the year 377 A.H./987 A. D. or approximately thirteen years after Yahya's death. Hence, by such time, all Yahya's writings might have been available and known by Ibn al-Nadim.

It is possible, therefore, that the title Tahdhib al-Akhlaq was not used by early Arabic biographers although they might have known about it by another name or title. The title Siyasa al-Nafs, which was mentioned by Ibn Abi Usaybi'a (1982) as a genuine work of Yahya, may refer to the present treatise. The expressions: siyasa al-nafs (the improvement/management of the soul), siyasa al-akhlaq (the improvement/refinement of character), tahdhib al-nafs (the refinement of the soul) and tahdhib al-akhlaq (the refinement of character), are not only used interchangeably by Yahya, but also appear to be synonymous. Both terms, siyasa and tahdhib connote almost the same meaning, i.e., "improvement", "management", "refinement" and the like; while the term al-nafs (soul) corresponds to that of al-akhlaq (character), since Yahya defines character as the state of the soul. Hence, Siyasa al-Nafs and Tahdhib al-Akhlaq, could probably have stood for the title of one single work under discussion. The fact that the former has not yet been found may substantiate this possibility. Furthermore, the expressions: siyasa al-akhlaq and tahdhib al-nafs are both employed by 
Yahya to describe the subject matter of the present Tahdhib al-Akhlaq in the concluding portion of the book.

Although neither Yahya himself, nor his contemporaries such as al-Sijistani (1974), al-Tawhdi $(1929,1953)$ and Miskawayh (1966) or others ascribe a treatise entitled Tahdhib al-Akhlaq to him, the weight of modern scholarly studies favours the view that Yahya is the true author of the present work. To name a few, we may state the studies by Augustin Perier (1920), Gerhard Endress (1977), and Naji al-Takriti (1978).

Nevertheless, the study on Tahdhib al-Akhlaq in this article will give a few more clues to help solve the problem of its authorship. Firstly, no references were made to either al-Qur'an or al-Hadith in the text. Despite the presence of the basmala at the beginning of some of the manuscripts and editions of the Tahdhib al-Akhlaq, it could have been added by the pens of its copyists or editors. Secondly, its author is rather reluctant to use the terms which have been in common use among the Muslims of his time. For instance, it is noticeable that the terms such as, ahl al-ilm, al-ruhban, al-zuhhad, al-kana'is and ru'asa' al-din are used everywhere in the text, instead of al- ulama', al-awliya', al-mutasawwifun, almasajid, al-imam and the like which have been widely accepted by Muslim writers then.

Further, the Tahdhib al-Akhlaq advises the one who wishes to improve his character to be moderate when taking alcoholic drinks or whenever possible to give up drinking completely. Muslim writers including Ibn al-Arabi (d. 1240), Ibn al-Haytham (d. 1039), and al-Jahiz (d. 868), to whom the present treatise has sometimes been attributed, would certainly not have been so permissive. This is also similar with respect to other Muslim scholars, for al-Qur'an (5: 93-94), for instance, prohibits: "0 ye who believe! Intoxicants and gambling, (dedication of) stones, and an abomination, - of Satan's handiwork: eschew such (abomination), that ye may prosper. Satan's plan is (but) to excite enmity and hatred between you, with intoxicants and gambling, and hinder you from the remembrance of God and from prayer: will ye not then abstain?" All these indications might suggest that its author could not have been a Muslim. Therefore, he must be a Christian, Yahya Ibn Adi. Here are brief outlines of Yahya's Tahdhib al-Akhlaq:

(i) Muqaddima (introduction): Why be Moral?

(ii) The Foundation of Ethics on the Tripartition of the Soul: the Rational, the Irascible and the Concupiscent.

(iii) List of Moral Virtues.

(iv) List of Moral Vices.

(v) Method of the Refinement of Character: on how the three Faculties of the Soul, namely, the Irascible, the Concupiscent, and the Rational can be controlled by Man.

(vi) The Character of the Perfect (Happy) Man and the Way towards Perfection.

\section{Conclusion}

In his survey of Muslim philosophy, Professor De Boer $(1970,17)$ remarked that: "The Syrians (Yahya probably being no exception), it is true, produced nothing original; but their activity as translators was of advantage to Arab-Persian science." However, our study on Yahya enables us to modify this statement, in the sense that Yahya was a translator with a strong theological interest, who never left his career at a purely commercial level, but sought to apply theology, in his own ways, into the practical ethical reality of his days. To this end, Peter's (1968:162) comment on his talent is in all probability correct: "Yahya was a commentator, and theologically, he was an apologist; in neither case did he leave behind a systematic presentation of his views".

\section{References}

Arberry, A.J. (1957). Revelation and Reason in Islam. London: George Allen \& Unwin Ltd.

Atiyeh, S.A. (1968). A History of Eastern Christianity. London: Methuen \& Co. Ltd.

Al-Bayhaqi. (1935). Tatimma Siwan al-Hikma. Edited by M. Shafi'. Lahore: L. Gurandifta Kapur.

Boer, T.J. De. (1970). The History of Philosophy In Islam, London: Luzac.

Endress, G. (1977). The Works of Yahya Ibn 'Adi. Wiesbaden: Dr. Ludwig Reichert Verlag.

Graf, G. (1910). De Philosophie und Gotteslehre des Jahja ibn 'Adi und spaterer Autoren. Munster.

Ibn Abi Usaybi'a. (1982, 1984). 'Uyun al-Anba' fi Tabaqat al-Atibba'. Edited by A. Muller. 2 vols. Konigsberg.

Ibn al-lbri. (1958). Ta'rikh Mukhtasar al-Duwal. Edited by A. Salihani. Beirut: Matba'a al-Kathulikiyya.

Ibn al-Nadim. (1871-1872). Kitab al-Fihrist. Edited by G. Flugel, J. Rodiger, and A. Muller. 2 vols. Leipzig: Verlag Von F.C.E. Vogel.

Kraemer, J. L. (1986). Humanism in the Renaissance of Islam: The Cultural Revival during the Buyid Age. Leiden: E.J. Brill.

Kraemer, J. L. (1986). Pbilosophy in the Renaissance of Islam: Abu Sulayman al-Sijistani and bis Circle. Leiden: E. J. Brill.

Meyerhof, M. (1984). Studies in Medieval Arabic Medicine. Edited by Penelope Johnstone. London: Variorum Reprints.

Meyerhof, M. (1930). Von Alexandrion nach Baghdad. Berlin: Verlaq Der Akademie Der Wissenschaften.

Miskawayh. (1966). Tahdhib al-Akhlaq. Edited C. K. Zurayk. Beirut: The American University of Beirut. 
Al-Mas'udi. (1893). al-Tanbih wa'l-Ishraf. Edited by M. J. de Goeje. Leiden: E.J. Brill. Perier, A. (1920). Yahya Ben 'Adi, Un Philosophe Arabe Chretien Du XE Siecle. Paris.

Peters, F. E. (1968). Aristotle and the Arabs: The Aristotelian Tradition in Islam. New York: New York University Press.

Al-Qifti. (1903). Ta'rikh al-Hukama'. Edited by J. Lippert. Leipzig: Dieterich's che-Verlags.

Rescher, Nicholas. (1964). The Development of Arabic Logic. Pittsburgs: University of Pittsburgh Press.

Samir, K. (1980). Maqala fi'l-Tawhid li'l-Shaykh Yahya Ibn 'Adi. Lubnan: al-Maktaba al-Bulusiyya.

Al-Sijistani. (1974). Muntakhab Siwan al-Hikma. Edited by 'A. R. Badawi. Teheran: Fondation Cultilrelle de l'Iran.

Edited by D. M. Dunlop. (1979). The Muntakhab Siwan al-Hikma of Abu Sulayman al-Sijistani. Berlin: W. De Gruyter.

Al-Takriti, Naji. (1978). Yahya Ibn 'Adi, A Critical Edition and Study of His Tahdhib al-Akhlaq, Beirut, Paris: Editions Oueidat.

Al-Tawhidi. (1953). al-Imta' wa'l-Mu'anasa. Edited by A. Amin and A. al-Zayn. 3 vols. Cairo: Matba'a Lujna al-Ta'lif wa'l-Tarjama wa'lNashr.

Al-Tawhidi. (1929). Al-Muqabasat. Edited by Hasan al-Sandubi. Cairo: al-Matba'a al-Rahmaniyya.

Walzer, Richard. (1962). Greek Into Arabic. Oxford: Bruno Cassirer.

Yahya Ibn 'Adi. (1978).Tahdhib al-Akhlaq. Edited by Naji al-Takriti in Yahya Ibn 'Adi: A Critical Edition and Study of his Tahdhib alAkhlaq. Beirut, Paris: Editions Oueida. 